22 - o problema juridico da liberdade segundo os pontos de vista de alguns filósóos contemporâneos (Referências críticas a Binder, Spirito e Stevenson).

23 - 0 problema da liberdade através dos princípios expressos pelos codigos brasileiro e italiano.

24 - Esclarecimento histórico-crítico dos conceitos de deliberação, inteligência prática e liberdade.

25 - Argumentos para defesa de um ponto de vista proposto em relação ao problema da liberdade no direito penal.

26 - Conclusão.

\title{
COMEMORAÇõES E SOLENIDADES
}

27 DE JANEIRO - Sessão solene da colação de gráu dos bacharelandos de 1953, paraninfados pelo professor Luís Antônio da Gama e Silva.

26 DE MARÇO - Aula solene de abertura dos cursos jurídicos, proferida pelo professor Luiz Eulálio ıde Bueno Vidigal, que discorreu sôbre o têma: "O ensino de Direito Processual Civil na Faculdade de Direito, nos últimos cem anos".

11 DE AGOSTO - Solenidades comemorativas do 1270 aniversário da fundação dos cursos juridicos no Brasil:

-às 9,00 horas, missa na igreja de São Francisco;

-às 10,00 horas, sessão solene da Congregação, e posse do doutor Goffredo da Silva Telles Junior no cargo de professor catedrático de Introdução à Ciência do Direito.

13 DE NOVEMBRO - Aula solene de encerramento do curso jurídico, proferida pelo professor Jorge Americano.

17 DE DEZEMBRO - Solenidades em homenagem a Dino Bueno, no centenário de seu nascimento:

-às 9,00 horas, missa na igreja de São Francisco;

-às 20,30 horas, sessão solene, falando em nome da Congregação o professor Candoso de Melo Neto. 